\title{
PENGARUH LAMA PAPARAN RADIASI MEDAN ELEKTROMAGNETIK HANDPHONE TERHADAP KADAR MALONDIALDEHID DAN KADAR KOLESTEROL PADA TIKUS (Rattus norvegicus) STRAIN WISTAR ALBINO
}

Resti Aulia Fitri ${ }^{1}$, Arni Amir ${ }^{2}$, Aswiyanti Asri ${ }^{3}$

\begin{abstract}
Abstrak
Paparan radiasi gelombang elektromagnetik handphonedapat menimbulkan gangguan pada organ tubuh dengan meningkatkan kadar malondialdehid dan menurunkan kadar kolesterol. Penelitian ini bertujuan untuk membuktikan paparan gelombang elektromagnetik handphonedapat meningkatkan kadar malondialdehid dan menurunkan kadar kolesterol pada tikus (Rattus novergicus) jantan galur wistar albino. Penelitian ini merupakan eksperimental dengan desain penelitian Post Test Only Control Groupyang menggunakan 24 ekor tikus (Rattus novergicus) jantan, galur wistar albino, berumur 2-3 bulan, yang terbagi menjadi 4 (empat) kelompok masing- masing berjumlah 6 ekor tikus. Kelompok kontrol (K) tidak diberikan paparan radiasi handphone. Kelompok perlakuan (P1) diberi paparan radiasihandphone 30 menit/hari, kelompok perlakuan 2 (P2) dengan paparan radiasi 60 handphonemenit/hari dan kelompok perlakuan 3 (P3) dengan paparan radiasi handphone 90 menit/hari selam 51 hari. Setelah dilakukan perlakuan selama 51 hari,darah diambil dari retro orbitalis dan kadar malondialdehid diperiksa dengan metode Thiobarbituric Reactive substances (TBARs) dan kadar kolesterol di ukur dengan metode Cholesterol Oxidase-Peroksidase Aminoantipyrine Phenol (CHOD-PAP). Hasil penelitian menunjukkan bahwa rerata kadar malondialdehid kelompok $\mathrm{K}$ ialah 2,376 nmol/ml, kelompok P1 2,890 nmol/ml, kelompok P2 3,306 nmol/ml, kelompok P3 3,800 nmol/ml. Rerata kadar kolesterol kelompok kontrol (K) $77,816 \mathrm{mg} / \mathrm{dl}$, kelompok perlakuan 1 (P1) 71,350 mg/dl, kelompok perlakuan 2 (P2) 71,173 mg/dl dan kelompok perlakuan 3 (P3) 70,916 mg/dl.Pada analisa data didapatkan kadar malondialdehid dan kadar kolesterol tikus $p<0,05$ berarti ada perbedan bermakna antar kelompok kontrol dengan kelompok perlakuan. Kesimpulan penelitian ini ada pengaruh lama paparan radiasi handphone terhadap kadar malondiladehid dan kadar kolesterol tikus jantan Rattus novergicus galur Wistar Albino.
\end{abstract}

Kata kunci: Radiasi elektromagnetik handphone, Malondialdehid, kolesterol

\begin{abstract}
Exposure to mobile phone electromagnetic radiation can cause interference with organs by increasing malondialdehyde levels and lowering cholesterol levels. This study aims to prove the exposure of electromagnetic waves mobile phones can increase levels of malondialdehid and reduce cholesterol levels in rats (Rattus novergicus) males wistar albino strain. The research type was experimental with Post Test Only Control Group research design using 24 male rats (Rattus novergicus), wistar albino strain, 2-3 months old, divided into 4 (four) groups of 6 rats each. The control group $(K)$ was not given exposure to cell phone radiation. The treatment group (P1) was exposed to mobile phone radiation 30 minutes / day, treatment group $2(P 2)$ with radiation exposure 60 minutes / day and treatment group 3 (P3) with cell phone radiation exposure 90 minutes / hr for 51 days. After 51 days of treatment, blood was taken from the retro orbitalis and the malondialdehid levels were examined by the method of Thiobarbituric Reactive substances (TBARs) and cholesterol levels measured by the Cholesterol Oxidase-Peroksidase Aminoantipyrine Phenol (CHOD$P A P)$ method. The results showed that the mean of $K$ group malondialdehid content were $2,376 \mathrm{nmol} / \mathrm{ml}, P 1 \mathrm{group}$ 2,890 nmol / ml, P2 group 3,306 nmol / ml, and P3 3,800 nmol / ml. Mean of control group cholesterol (K) 77,816 mg / dl, treatment group 1 (P1) 71,350 mg / dl, treatment group 2 (P2) 71,173 mg / dl and treatment group 3 (P3) 70,916 mg / dl. malondialdehid levels and cholesterol levels of $p<0,05$ mean that there is a significant difference between the control group and the treatment group. It can be concluded that there are long effect of cell phone radiation exposure to malondiladehid level and cholesterol level of Rattus novergicus Wistar Albino rats.
\end{abstract}

Keywords: Electromagnetic radiation, mobile phone, malondialdehyde and cholesterol

Affiliasi penulis :1. Program Studi Magister S2 Biomedik FK UNAND, 2.Bagian Biologi FK UNAND, 3.Bagian Patologi Anatomi FK UNAND Korespondensi :Resti Aulia Fitri

email: restiauliafitri02@gmail.com,Telp: 085263913771

\section{PENDAHULUAN}

Komunikasi dapat berlangsung dari mana saja, baik secara langsung maupun tidak langsung. Misalkan dengan menggunakan media komunikasi berupa handphone yang sekarang ini sedang trend di

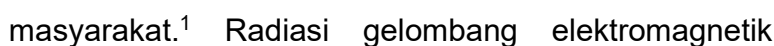
handphone berpotensi menimbulkan gangguan pada berbagai organ tubuh dan bersifat karsinogenik baik secara thermal maupun non -thermal. ${ }^{2}$

Mekanisme pengaruh elektromagnetik terhadap kesehatan adalah adanya perubahan keseimbangan kadar radikal bebas dalam system biologik. Ketidakseimbangan kadar radikal bebas akan menyebabkan terjadinya stress oksidatif. Stres oksidatif akan meningkatkan peroksidasi lipid, peroksidasi lipid akan menghasilkan senyawa- 
senyawa aldehid diantaranya malondialdehid, propanal, heksanal, dan 4-hydroxynonenal (4-HNE). ${ }^{3,4}$.

Paparan gelombang elektromagnetik dapat menyebabkan stress fisik dimana tubuh merespon dengan mengeluarkan hormone dari hipotalamus. Peningkatan sekresi hormon di hipotalamus mengakibatkan peningkatan kadar hormone glukokortikoid sehingga meningkatkan kadar kortisol akan menyebabkan penurunan kadar HMG KoA Reduktase. Penurunan kadar HMG KoA reduktase akan menyebabkan penurunan laju sintesis endogen dari kolesterol. Penurunan sintesis endogen akan meyebabkan penurunan kadar kolesterol di dalam plasma. ${ }^{5}$

Beberapa laporan yang membahas efek yang mendasari paparan radiasi handphone yang meningkatkan kadar malondialdehid dan menurunkan kadar kolesterol. Penelitian paparan gelombang elektromagnetik menggunakan frekuensi sebesar $1800 \mathrm{MHz}$ selama 15 menit dalam 5 hari berturutturutdapat meningkatan kadar malondialdehid (MDA) pada darah, otak dan ginjal tikus wistar. 6 Paparan radiasi radio frekuensi terhadap eritosit manusia menunjukan terjadinya peningkatan lipid peroksidase setelah 1 dan 2 jam pemaparan. ${ }^{7}$ Paparan medan magnet $50 \mathrm{~Hz}$ selama 15 menit dengan densitas 1,5 dan $12 \mathrm{mT}$ menunjukan terjadinya penurunan pada kadar kolesterol dan trigliserida dalam plasma. ${ }^{8}$

Penelitian ini bertujuan untuk melihat pengaruh lama paparan radiasi medan elektromagnetik handphone terhadap kadar malondialdehid dan kadar kolesterolRattus novergicus galur wistar albino.

\section{METODE}

Penelitian ini dilakukan Animal House dan Laboratorium Biokimia Fakultas Kedokteran Universitas Andalas selama kurang lebih 3 bulan. Penelitian ini merupakan penelitian eksperimen dengan desain Post-Test Only Control Group. Populasi pada penelitian ini adalah tikus Wistar, sampel yang digunakan adalah tikus jantan yang memiliki kriteria inklusi, tikus berjenis kelamin jantan, memiliki berat badan 200-300 gr. Jumlah sampel 24 ekor tikus. Sampel dibagi menjadi 4 kelompok, terdiri dari kelompok kontrol dan kelompok perlakuan, kelompok kontrol tanpa pemaparan radiasi handphone, sedangkan kelompok perlakuan diberikan masingmasing dengan paparan 30, 60 dan 90 menit, perlakuan diberi selama 51 hari, pada hari ke 52 dilakukan pengambilan darah pada tikus.

Darah tikus diambil melalui retro orbital dengan cara menusukkan pipa kapiler $2 \mathrm{~cm}$ ke cabang vena opthalmicus yang terletak di schantus medianus orbitalis, kemudian dilakukan sentrifugasi dengan kecepatan 3000 rpm selama 15 menit. Langkah berikutnya dilakukan pemeriksaan kadar malondialdehid yang diukur dengan menggunakan metode TBARs. Pemeriksaan kadar kolesterol dengan menggunakan metode CHOD-PAP. Pemeriksaan kadar malondialdehid dan kadar kolesterol serum, dilakukan di Laboratorium Biokimia FK Unand.

Penelitian ini telah mendapatkan persetujuan etik dari Panitia Etik Penelitian di Fakultas Kedokteran Universitas Andalas.Data kadar malondialdehid dan kadar kolesterol yang diperoleh dianalisis dengan uji one way ANOVA danMultiple Comparisons (post hoct test) jenis Bonferroni.

HASIL
Tabel 1. Nilai Rata-rata Kadar Malondialdehid Tikus Albino pada Kelompok Kontrol dan Perlakuan Setelah Dipapar Radiasi Handphone

\begin{tabular}{ccc}
\hline Kelompok & $\begin{array}{c}\text { Kadar malondialdehid } \\
(\text { nmol/ml) } \\
\text { Mean } \pm \text { SD }\end{array}$ & $P$ \\
\hline Kontrol & $2,376 \pm 0,207$ & \\
P-1(30') & $2,890 \pm 0110$ & 0,000 \\
P-2(60') & $3,306 \pm 0,367$ & \\
P-3(90') & $3,800 \pm 0,095$ & \\
\hline
\end{tabular}

*Nilai $p$ didapat dari uji oneway Anova

Tabel 1. menunjukkan bahwa kadarmalondialdehid pada kelompok kontrol dan perlakuan terdapat perbedaan yang bermakna ( $p<$ $0,05)$, dimana nilai $p=0,000$.

Tabel 2. Hasil Uji Multiple Comparisons (Post Hoc Test) jenis Bonferroni terhadap Kadar MalondialdehidTikus Wistar Albino pada Kelompok Kontrol dan Kelompok Perlakuan

\begin{tabular}{llcccc}
\hline NO & \multicolumn{2}{l}{ Kelompok Kontrol } & P-1 & P-2 & P-3 \\
\hline 1 & Kontrol & - & 0,004 & 0,000 & 0,000 \\
2 & P-1(30') & 0,004 & - & 0,025 & 0,000 \\
3 & P-2(60') & 0,000 & 0,025 & - & 0.006 \\
4 & P-3(90') & 0,000 & 0,000 & 0,006 & - \\
\hline
\end{tabular}

Tabel 2. menunjukkan hasil uji Multiple Comparisons (Post Hoc Test) jenis Bonferroni didapatkan bahwa terdapat perbedaan yang signifikan antara kelompok kontrol dengan perlakuan, dengan nilai signifikan $<0,05$.

Tabel 3. Nilai Rata-rata kadar kolesterol Tikus Albino pada Kelompok Kontrol dan Perlakuan Setelah Dipapar radiasi handphone

\begin{tabular}{ccc}
\hline Kelompok & $\begin{array}{c}\text { Kadar Kolesterol } \\
\text { Mean } \pm \text { SD }\end{array}$ & $\boldsymbol{P}$ \\
\hline Kontrol & $77,816 \pm 2,865$ & \\
P-1(30') & $71,350 \pm 2,201$ & 0,014 \\
P-2(60') & $71,178 \pm 5,779$ & \\
P-3(90') & $70,916 \pm 3,472$ & \\
\hline
\end{tabular}

${ }^{*}$ Nilai $p$ didapat dari uji oneway Anova

Tabel 3 menunjukkan bahwa jumlah spermatozoa pada kelompok kontrol dan perlakuan terdapat perbedaan yang bermakna $(p<0,05)$, dimana nilai $p=$ 0,014

Tabel 4 Hasil Uji Multiple Comparisons (Post Hoc Test) jenis Bonferroni terhadap kadar kolesterolTikus Wistar Albino pada Kelompok Kontrol dan Kelompok Perlakuan

\begin{tabular}{llcccc}
\hline NO & Kelompok & Kontrol & P-1 & P-2 & P-3 \\
\hline 1 & Kontrol & - & 0,050 & 0,042 & 0,032 \\
2 & P-1(30') & 0,050 & - & 1,000 & 1,000 \\
3 & P-2(60') & 0,042 & 1,000 & - & 1,000 \\
4 & P-3(90') & 0,032 & 1,000 & 1,000 & - \\
\hline
\end{tabular}

Tabel 4 menunjukkan hasil uji Multiple Comparisons (Post Hoc Test) jenis Bonferroni didapatkan bahwa terdapat perbedaan yang signifikan antara kelompok kontrol dengan kelompok perlakuan dengan nilai signifikan $<0,05$. 


\section{PEMBAHASAN}

\section{Pengaruh Lama Paparan Radiasi medan elektromagnetik handphone terhadap Kadar MalondialdehidTikus Wistar Albino}

Berdasarkan uji Oneway Anova didapatkan bahwa $p<0,05$ dengan nilai $p$ yaitu 0,000 yang berarti terdapat pengaruh lama paparan radiasi handphoneterhadap kadarmalondialdehid tikus wistar albino antara kelompok kontrol dengan kelompok perlakuan.

Penelitian ini menunjukkan kadar malondialdehid pada kelompok perlakuan yang dipapar radiasi handphonelebih tinggi,dibandingkan dengan kelompok kontrol tampa pemaparan radiasi handphone. Malondialdehid terbentuk dari peroksidasi lipid (lipid peroxidation) pada membran sel yaitu reaksi radikal bebas (radikal hidroksi) dengan Poly Unsaturated Fatty Acid (PUFA). Reaksi tersebut terjadi secara berantai, akibat akhir dari reaksi rantai tersebut akan terbentuk hidrogen peroksida $\left(\mathrm{H}_{2} \mathrm{O}_{2}\right)$ yang akan menjadi radikal hidroksil $\left(\mathrm{OH}^{*}\right) .^{9}$

Terjadinya peroksidasi lipid pada membran sel oleh radikal bebas dapat mengakibatkan hilangnya fungsi sel. Dalam reaksi peroksidasi lipid akan menghasilkan berbagai produk termasuk aldehid rantai pendek seperti malondialdehid. Konsentrasi malondialdehid yang tinggi menunjukkan adanya proses oksidasi dalam membran sel. Paparan yang terjadi dalam waktu lama dan terus menerus dapat menyebabkan kerusakan sel. Kerusakan dari struktur sel mengakibatkan penurunan fungsi dan kematian pada sel. ${ }^{9}$

Penelitian ini sejalan dengan kesari 2011 yang menyatakan bahwa. Pemaran radiasi elektromagnetik selama 4 minggu dapat meningkatkan kadar malondialdehid dan menurunkan antioksidan glutation dismutase (GSH). ${ }^{10}$ Sama halnya dengan Bodera yang menyimpulkan pemaparan gelombang elektromagnetik dengan frekuensi $1800 \mathrm{Mhz}$ selama 15 menit perhari mampu meningkatkan kadar malondialdehid pada darah tikus. ${ }^{6}$

\section{Pengaruh Lama Paparan Radiasi Medan Elektromagnetik handphone terhadap Kadar Kolesterol Tikus Wistar Albino \\ Berdasarkan uji oneway Anova didapatkan bahwa} $p<0,05$ dengan nilai $p$ yaitu 0,014 yang berarti terdapat pengaruh lama paparan radiasi handphoneterhadap kadar kolesteroltikus wistar albino antara kelompok kontrol dengan kelompok perlakuan.

Pada penelitian ini kadar kolesterol pada kelompok kontrol lebih rendah dibandingkan dengan kelompok perlakuan. Rendahnya kadar kolesterol disebabkan karena stres fisik dan psikis yang ditimbulkan oleh paparan radiasi gelombang elektromagnetik handphone.

Setiap stres fisik dan psikologis dalam waktu singkat hanya beberapa menit sudah dapat meningkatkan sekresi ACTH dan akibatnya sekresi glukokortikoid dan kortisol juga akan meningkat ${ }^{5}$. Glukokortikoid berperan penting bagi katekolamin untuk menerapkan efek mobilisasi asam lemak bebas secara penuh. ${ }^{11}$ Peningkatan hormon glukokortikoid, juga akan peningkatan sekresi hormon epinefrin dan norepinefrin, kedua hormon ini dapat meningkatkan laju lipolisis di jaringan adiposa ${ }^{12}$, selain itu norepinefrin juga dapat meningkatkan penggunaan lipoprotein sirkulasi, sehingga kadar kolesterol yang terdapat dalam plasma akan menurun. ${ }^{5}$ Kortisol diproduksi lebih banyak oleh tubuh pada saat tubuh terpapar stres, baik fisik maupun psikologis. Kortisol dapat memodulasi sistem imun karena semua leukosit mempunyai reseptor untuk kortisol. Kenaikan kadar kortisol akan menyebabkan penurunan kadar HMG KoA Reduktase. ${ }^{5}$ Penurunan kadar HMG KoA reduktase akan menyebabkan penurunan laju sintesis endogen dari kolesterol. Penurunan sintesis endogen akan meyebabkan penurunan kadar kolesterol di dalam plasma.

Penelitian ini sama dengan penelitian yang dilakukan oleh Luo 2004, bahwa tikus yang dipapar radiasi handphone dapat menyebabkan penurunan kadar kolesterol. ${ }^{13}$

\section{SIMPULAN}

Pemberian paparan radiasi handpone dapat meningkatkan kadar malondialdehid dan menurunkan kadar kolesterol tikus Wistar Albino.

\section{UCAPAN TERIMA KASIH}

Penulis mengucapkan terimakasih kepada Kepala dan Staf Laboratorium Biokimia FK-Unand yang telah membantu pemeriksaan sampel.

\section{DAFTAR PUSTAKA}

1. Rochajat $\mathrm{H}$, Ardianto E. Komunikasi pembangunan dan perubahan sosial. Jakarta: PT Raja Grafindo Persada. 2011;56-57

2. Swamardika IBA. Pengaruh Radiasi gelombang elektromagnetik terhadap kesehatan manusia Teknologi Elektro Jurnal . 2009; 8(1) : 06-109

3. Ayala A, Munoz MF,Argüelles S. Lipid Peroxidation: Production, Metabolism, and Signaling Mechanisms of Malondialdehyde and 4-Hydroxy-2-Nonenal. Oxid med cell. 2014;14 (1):1-31

4. Shah D, Mahajan N, Sah S, Nath SK, Paudyal B. Oxidative stress and its biomarkers in systemic lupus erythematosus. J.Biomed. 2014;21(1):23

5. Mayes PA. Sintesis pengangkutan dan eksresi kolesterol. Dalam Murray RK, Graner DK Mayes PA, Rodwel VW. Biokimia Harper. Penerjemah; manurung, Lilian R, Mandera, Lydia I.Jakarta: Penerbit Buku Kedokteran EGC. 2009;279-290

6. Bodera P, Stankiewicz W, Antkowiak B, Paluch, $M$, Kieliszek J, Sobiech J. Influence of Electromagnetic Field ( 1800 Mhz ) on Lipid Peroxidation in Brain, Blood, Liver And Kidney In Rats. Int .J Occup Med Environ Health. 2015; 28(4):751-759

7. Zwirka-Korczala K, Jochem J, Adamezyk-Sowa, $M$, Sowa P, Polaniak R, Birkner E, Latocha M., Pilc K, Suchanek R. Efek of Extremely Low Freuency Elektromagnetik Field on Cell Proliferation, Antioksidative Enzyme Activities and Lipid Peroxidation in 3T3-LI Preadipocytesan Invitro Study. J Phisiol Pharmacol. 2005;56 (6): 101-108.

8. Harakawa S, Kunihito T, Nagasawa H. Effects of Exsposure to a $50 \mathrm{~Hz}$ Elektric Field on Plasma Levels of Lactate, Glucose, Free Fatty Acids, Triglycerides and Creatine Phospokinase Activity in Hind-Limd Ischemic Rats.J. Vet. Med. Sci. 2005; 67(10):969-974.

9. Putri IN. Pengaruh Paparan Gelombang Elektromagnetik Terhadap Kadar Kolesterol Total 
dan Trigliserida Serum. [Tesis]. Lampung: Universitas Lampung. 2011.

10. Kesari KK, Kumar S, Behari J. Mobile phone usage and male infertility in wistar rats. Indian Journal of Experimental Biology. 2011; 47:987992.

11. Ganong FW . Buku Ajar Fisiologi Kedokteran. Edisi ke-24.Editor Bahasa Indonesia: Djauhari Wijayakusumah. Jakarta: EGC. 2015; Hal: 293296.

12. Mailankoat $M$, Kunnath $A P$, Jayalekshmi, $H$, Koduru B, Valsalan R. Radio frequency electromagnetic radiation (RF-EMR) from GSM $(0.9 / 1.8 \mathrm{GHz})$ mobile phones induces oxidative stress and reduces sperm motility in rats. Clinical Science. 2009; 64 (6):561-5

13. Luo EP, Jiao LC, Shen GH, Wu XM, Cao YX .. Effect of Exposing Rabbits to Low-intensity Pulsed Elektromagnetic Field on Level of Bood Lipid and Properties of Hemorheology. Chinese journal of Clinical Rehabilitation. 2004;8(18) :3670-3674 